\title{
Baha Kalinowska-Sufinowicz*
}

\section{Telework as a form of limiting human and social capital depreciation among parents with young children}

The main goal of the article is to present telework as a form of employment for parents with young children and its evaluation in the context of methods counteracting the depreciation of human and social capital - both from the labour demand and labour supply perspectives. The paper consists of two parts: a theoretical perspective and a practical one. The first part of the paper begins with a reflection on the phenomena of the depreciation of human and social capital in the light of literature review, especially with reference to the situation of parents raising young children. In the following - more practical - section, the concept and types of telework are introduced as well as its advantages and disadvantages from the points of view of employers and employees.

\section{Introduction}

Since the 1990s, intensive demographic changes have been observed in Poland. These changes are characterised by the decrease of total fertility rate (on the one hand) and the increase of average life expectancy (on the other). As a result, the population structure by economic age has changed, which has macroeconomic consequences for the labour market (limited labour resources, among others) as well as increasing burdens on the state budget in the long run.

The situation on the labour market is, therefore, determined by demographic changes, and at the same time, it conditions their existence and development. The phenomenon of unemployment in Poland affects women to a greater extent than men due to the fact that employers regard women as potential mothers and

* Poznań University of Economics and Business, Departament of Macroeconomics and National Economy Research, e-mail: baha.kalinowska@ue.poznan.pl 
more "troublesome". Such a perception lowers the competitiveness of women as potential employees and, at the same time, affects procreational decisions. It is also worth emphasising that a higher level of unemployment among women means greater exposure to the depreciation of human and social capital.

The subject of this paper is a reflection on telework as an opportunity to reduce the conflict between work and family life; in particular, taking care of young children. This form of work can provide a solution to prevent the depreciation of human and social capital in the group of parents raising young children - both women and men. The main goal of the article is to present telework as a form of employment for parents with young children as well as its evaluation in the context of methods counteracting the depreciation of human and social capital both from the labour demand and labour supply perspectives. The paper consists of two parts: a theoretical portion and a practical one. The first part of the paper begins with a reflection on the phenomena of the depreciation of human and social capital in the light of literature review, especially with reference to the situation of parents raising young children. In the following - more practical - section, the concept and types of telework are introduced as well as its advantages and disadvantages from the points of view of employers and employees.

\section{Human and social capital and the question of parenthood}

The concept of human capital in the literature of the subject can be understood in different ways. Human capital can be understood as people who are the basis for estimating the value. Models of human capital participation in creating economic growth (i.e., the Cobb-Douglas economic growth model or the Solow-Swan model of economic growth) are set within this perspective. Another approach treats man and human capital separately, and human capital is understood as accumulated skills, abilities, knowledge, energy, and health that are the result of specific inputs (Kunasz, 2004). In this approach, human capital is most often considered as the factor decisive for the situation on the labor market (for example, human capital theories that explain the functioning of the labour market or the occurrence of discrimination on this market).

It is worth noting that the human capital theory was developed by many economists, including Theodore Schultz, Gary Becker, Jacob Mincer, and Solomon Polachek. In this theory, there is an interesting element concerning the impact of parenthood (particularly maternity) on human capital and the labour market situation. In 1958, Mincer pointed out that earnings of female workers were "less 
Telework as a form of limiting human and social capital depreciation...

dispersed than earnings of male workers", and also that "earnings of male fullperiod workers who are heads of families are more unequal than those of single men" (Mincer, 1958). Later, in 1974, Mincer and Polachek compared the levels of earnings among married women, married men, and unmarried women. They expressed the opinion that "the loss or reduction of market earnings of mothers due to demands on their time in child rearing represents a measure of family investment in the human capital of their children. The investment cost has been measured by valuing the reduction of market time at the observed wage rate" (Mincer and Polacheck, 1974). In 1982, in turn, Mincer and Haim Ofek made a comparison of real earnings attained at the beginning and end of a professional career. They found out that the longer the child-related career break, the greater the differences between the level of earnings at the end of a professional career (Mincer and Ofek, 1982). Polachek believed that one of the causes of these differences between the levels of earnings was the depreciation of human capital, which occurs during breaks in women's professional careers.

The issue of social capital, discussed by James Coleman, is also interesting from the point of view of the situation of parents (particularly mothers) on the labour market. In 1988, he distinguished "three forms of social capital: obligations and expectations, information channels, and social norms". What is more, Coleman highlighted "one effect of social capital that is especially important: its effect on the creation of human capital in the next generation" (Coleman, 1988).

Although child-related career breaks are treated as "family investment in the human capital of next generation", they without a doubt contribute to the prevalence of depreciation of human and social capital. On the one hand, knowledge and skills are forgotten; on the other, interpersonal relationships vanish. Later, these factors become significant limitations to professional reactivation, which most often affects women/mothers. The fear of "dropping out" from the labour market results in postponing the decision to become a mother, which in turn leads to lower fertility among women. Taking this into account, it is worth considering one of the solutions that may be used to help the group of parents raising young children. At the same time, it should be pointed out that the solution has both advantages and disadvantages, but it is worth further consideration in the context of reducing the phenomenon of depreciation of human and social capital.

\section{The concept of telework}

Contrary to appearances, it is not so easy to define telework. Maria Montesano claims that "teleworking is not a job" but rather "a way of working". She also adds 
that "teleworking is also known as "working from home", "telecommuting", "cyber working”, "mobile working”, and "e-working” (Montesano, 2010).

According to Jack M. Nilles (a theorist of this phenomenon), telecommuting is defined as the partial or total substitution of telecommunications, with or without the assistance of computers, for the commute to/from work (Nilles, 1994).

Janusz Wiśniewski defines teleworking as the form of organisation and/or performance of work using information technology in which a major part of the employee's time that could be carried out in the premises of the employer is regularly done offsite, within the framework of the employment contract (Wiśniewski, 2007).

In accordance with the Polish Labour Code, telework occurs when work is performed regularly away from the traditional office using electronic communication (Ustawa z 26 czerwca 1974..., 2014). Some doubts might arise due to the fact that "regularity" of work by teleworker away from the traditional office is not precisely defined. Does it mean that daily working from home must continue for 8 hours a day? Or is it enough if the working parent takes work home for 2 or 3 days per week (for example, due to the illness of his/her child)? Or what about a situation in which a working parent spends 5 hours in the company, for example, and he or she works remotely from home or from another location outside the traditional office during the remaining 3 hours? Can this be called telework?

In the Polish Labour Code, there are no answers to these questions. However, it does specify the responsibilities of the employer who engages employees in the form of telework, which basically includes the obligation to provide the necessary equipment (along with its insurance) to cover the costs associated with its installation, service, maintenance, and operation. The provision of technical assistance and the necessary training on hardware support are also included (Ustawa $z 26$ czerwca 1974..., 2014). Although there is a possibility of using other solutions, this provision is sometimes regarded as overly burdensome by employers, especially taking into account the potential resignation of a teleworker within 3 months without providing reasons for such a decision. In this context, and from the point of view of employers, teleworking may be quite a costly investment in human capital in the enterprise.

\section{Types of telework}

Based on the place of employment and the information technology used by the teleworker to provide work, several types of telework can be distinguished. One of the most useful approaches is the division of telework into three main groups: 
Telework as a form of limiting human and social capital depreciation...

- working from home,

- working away from the traditional office,

- mobile teleworking (Wiśniewski, 2007).

It is worth presenting the fundamental differences between these types of telework.

Home working means performing work at home and communicating with the employer by means of an appropriate means of communication (Wiśniewski, 2007). On the one hand, it might be typical full-time teleworking; or on the other hand, occasional telecommuting in a situation when a young child is ill and the employee may provide work from home at the time of childcare. The English "homeoffice" term is commonly used in Poland. In telecommuting, in turn, work is provided away from the traditional office but in an ordinary fixed place. Various forms of this type of teleworking can be identified (Auriga, 2005; Kalinowska-Nawrotek, 2005); for example:

- a telecentre (also known as a call center) - a work location that is usually in a different place than the headquarters of the organization; it provides access for telecommuting to work equipment; it can be compared to a subsidiary or a branch office;

- telecottages - special kind of telecentres located in rural areas;

- virtual enterprises - involving cooperation between legally and spatially separate business entities working on-line on a certain specific project;

- overseas teleworking - when the recruitment net includes people living in other cities, regional and rural places, or even from overseas.

Mobile teleworking is performed in any location where the teleworker is at a given moment. Thus, the place of providing telework is changeable - it can be either working at home or at the company of a client. A teleworker can also keep in contact with the employer by individual or mass means of communication, even from a car (Kalinowska-Nawrotek, 2005; Wisniewski, 2007).

Irrespective of the definition problems, the legal solutions adopted in the Polish Labour Code and the choice of the teleworking type, it should be pointed out that this option is one of the flexible forms of employment and the organization of working time, which seems to be a win-win proposition both for women (including those who return to the labour market after maternity leave (Kalinowska-Sufinowicz, 2013) and for men (who want to actively participate in the upbringing of their children). It is worth discussing the advantages and disadvantages of telework more thoroughly. 


\section{The positive aspects of teleworking}

In the beginning, it is important to consider the benefits that result from the implementation of telework for employers (see Table 1). The use of this form allows an employer to reduce the cost of operation of the company by reducing the necessary office space, but also to increase the number of employees at the same office space (meaning average labour productivity rises). Besides, teleworking makes it possible to acquire qualified and highly educated people, even if that they cannot be found on the local labour market (Kalinowska-Nawrotek 2005; Kalinowska, 2007); and as a result, this increases the resources of human capital in the company.

Table 1

Advantages of telework for the employer and employee (with young children)

\begin{tabular}{|c|c|}
\hline Employer & Employee \\
\hline reducing employment costs & $\begin{array}{l}\text { avoiding time- and } \\
\text { money-consuming commuting and reduc- } \\
\text { ing babysitter costs }\end{array}$ \\
\hline higher employee productivity & a better chance of finding a suitable job \\
\hline better access to employees & $\begin{array}{l}\text { a higher possibility of attaining a work-life } \\
\text { balance }\end{array}$ \\
\hline $\begin{array}{l}\text { a greater chance of increasing } \\
\text { the human capital resources } \\
\text { in the company }\end{array}$ & $\begin{array}{c}\text { greater opportunities for professional } \\
\text { development }\end{array}$ \\
\hline $\begin{array}{l}\text { lower employment turnover and lower } \\
\text { cost of staff recruitment }\end{array}$ & greater motivation to work \\
\hline $\begin{array}{l}\text { elimination of stress associated with the } \\
\text { use of ad hoc solutions }\end{array}$ & $\begin{array}{l}\text { elimination of stress associated with the } \\
\text { use of ad hoc solutions }\end{array}$ \\
\hline
\end{tabular}

Source: own study on the basis of (Głogosz et al. 2007a; Głogosz et al. 2007b)

Telecommuting also allows for a reduction in employment rotation, and thus, the reduction of costs of staff recruitment. For example, instead of using sick leave, a pregnant employee may work from home, adjusting the pace of work to her well-being and health status.

Working parents with young children who choose the option of homeoffice (away from the traditional office) will be able to reconcile the work at home with the care for a sick child without the necessity of using sick leave or childcare leave. 
Telework as a form of limiting human and social capital depreciation...

The employer does not have to worry about replacing such a person in the workplace in a situation of having to stay with a sick child at home. The work performed from home will be more effective than in the situation of substituting the worker with someone else without prior preparation.

As for employees, telework allows them to avoid expenses for communing, to reduce tiredness, and to save time by not commuting (usually during rush hours). When a teleworker spends more time at home, he or she has greater opportunities for work-life balance and for professional development. Because the teleworker can start working earlier, he or she gets extra time to spend with their child and can read a professional book to expand his or her competence, for example. The use of teleworking also helps reduce expenses for babysitters or other forms of emergency care for a sick child. Even if a teleworker is forced to employ a babysitter, he or she will be more relaxed thanks to being around and in greater control of the situation (e.g., administering medication to the child).

Given that telework may be provided practically from any place where there is access to telecommunication and/or information technologies, it should be pointed out that this form of work gives greater opportunities of finding a job than limiting oneself to one's local municipality. What is more, an employee who teleworks is usually more satisfied, loyal, and is characterised by a stronger motivation to work. A teleworker will also feel more relaxed and less tense than if he or she used sick-child leave or child-care leave, fearing the negative consequences of reduced attendance at work on the part of the employer.

\section{Limitations of telework}

As mentioned above, it is quite risky for employers to bear the costs of organising the worksite for teleworkers who may opt out of this form of work up to 3 months after starting it (see Table 2). The control and supervision of an employee is also quite difficult when he or she is at home or wherever he or she is working at the moment. When the teleworker does not properly understand the methods used in the job, he or she may temporarily work less effectively. Besides, the employer has less contact with the teleworker who is not physically present in the company. This last factor also promotes atomisation of labour relations in the enterprise and does not facilitate the management of subordinates. Hiring teleworkers requires, in fact, developing new forms of contact and learning new management techniques using the Internet. 
Table 2

Disadvantages of telework for the employer and for the employee

\begin{tabular}{|c|c|}
\hline Employer & Employee \\
\hline $\begin{array}{c}\text { the costs and risks of organization of the } \\
\text { teleworking place }\end{array}$ & $\begin{array}{c}\text { the lack of resolution between working } \\
\text { time and time off }\end{array}$ \\
\hline $\begin{array}{c}\text { problems with the supervision of the } \\
\text { teleworker }\end{array}$ & $\begin{array}{c}\text { limited contact with the working } \\
\text { environment }\end{array}$ \\
\hline $\begin{array}{c}\text { worse quality of work can be } \\
\text { observed temporarily }\end{array}$ & limited access to information \\
\hline a barrier of resistance to change & less motivation to work \\
\hline the atomisation of labour relations & limited access to training, promotion, \\
and employee benefits
\end{tabular}

Source: own study on the basis of (Głogosz et al. 2007a; Głogosz et al. 2007b)

Telecommuting can also be difficult for the employee. The inability of "closing the door" every day after finishing work causes a blurring of the line between working time and time off, often to the detriment of the latter. The lack of social contacts or a motivation to dress smartly when leaving home to meet other people can lead to depressive moods in a teleworker, and less motivation to work. Not everyone is suited to work independently and to manage his or her time effectively and efficiently. Sometimes, it is not easy to explain to the family that "I am home" can mean "I am working." Moreover, because of being away from the traditional office, the teleworker may have limited access to information, which could result in limited access to training, promotion, or employee benefits. It is very easy to forget about a teleworker who is not physically in the company, especially when allocating cash bonuses or other additional benefits.

\section{Conclusion}

One of the reasons for the decrease of total fertility rate is women's fear of the deterioration of their situation on the labour market. The child-related career breaks cause the depreciation of human and social capital, which is a significant limitation of the employability of young parents raising young children (women in particular). The solution that is proposed in this paper is telecommuting. 
Telework as a form of limiting human and social capital depreciation...

Despite the difficulties in defining and in implementing legal solutions, telework is regarded as an option recommended particularly for working parents who care for young children - recommended by both employees and employers. Many advantages of telework were analysed in this paper. For employers, telework mostly allows for a reduction in employment costs, greater employee productivity, a better chance to increase human capital in the company, and better access to employees. It also allows for lower employment turnover, lower costs of staff recruitment, and the elimination of stress associated with the use of ad hoc solutions. For employees, telework gives them a chance to find a suitable job, to lower communing expenses, to reduce costs of babysitting, and for professional development. But above all, it allows them to achieve a better reconciliation of work and family life, which also is associated with a greater motivation to work, an elimination of nerve-racking ad hoc solutions, and the reduction of the depreciation of human and social capital.

It should be noted that not all companies are able to introduce solutions such as telework because of the nature of their business (e.g., among personal service workers or among employees whose physical presence is required at a traditional office). But sometimes the limited use of teleworking is a result of lack of theoretical and practical knowledge about this solution (both among employers and workers) as well as a lack of employer trust in the employees. Among the restrictions of teleworking from the point of view of the employer, there are also the costs and risks of organising a worksite away from the traditional office and worse quality of work (at least temporarily), as well as problems with the control of teleworker, a barrier of resistance to change, and an atomisation of labour relations. In turn, for employees, the disadvantages of telework can be the lack of separation of working time and time-off as well as limited access to building social capital, information, training, promotion, career development, and benefits, as well as even less motivation to work.

It is worth noting that telework may not be a commonly used solution because of the limitations associated with specific features of the industry in which the employee works, but also micro-social limitations. Telecommuting requires high self-organisation and reliability in carrying out tasks without constant control and supervision. The flexibility of this solution does not mean the disorganisation of tasks and procrastination, because this could lead to the creation of backlogs and, as a consequence, the loss of the job.

However, there are many positive aspects of teleworking. One of the most important is reducing the depreciation of human and social capital; hence, for working parents (both women and men who care for young children), telecommuting seems to be a highly attractive solution. Teleworking means a greater possibility of attaining a work-life balance than in the situation of work from a traditional office in the standard work-time system for 8 hours a day, 5 days a week, and fixed working hours. 


\section{References}

[1] Auriga, R. (2005) 'O formach i społecznych konsekwencjach elastyczności pracy', in Polityka Społeczna. Wybrane problemy. Wybór artykułów z lat 1999-2005, Instytut Pracy i Spraw Socjalnych, Warszawa.

[2] Coleman, J. (1988) 'Social Capital in the Creation of Human Capital', The American Journal of Sociology, vol. 94, Supplement: Organizations and Institutions: Sociological and Economic Approaches to the Analysis of Social Structure, pp. S95-S120.

[3] Głogosz, D., Machol-Zajda, L., Sadowska-Snarska, C. and Wojciechowski, P. (2007a) Elastyczne formy pracy. Poradnik dla pracodawców, Białystok: Wydawnictwo Wyższej Szkoły Ekonomicznej w Białymstoku.

[4] Głogosz, D., Machol-Zajda, L., Sadowska-Snarska, C. and Wojciechowski, P. (2007b). Elastyczne formy pracy. Poradnik dla pracowników, Białystok: Wydawnictwo Wyższej Szkoły Ekonomicznej w Białymstoku

[5] Kalinowska-Nawrotek, B. (2005) Dyskryminacja kobiet na polskim rynku pracy, Poznań: Wydawnictwo Akademii Ekonomicznej w Poznaniu.

[6] Kalinowska, B. (2007) 'Elastyczne formy zatrudnienia i organizacji pracy w przedsiębiorstwie', in Jarmołowicz, W. (ed.) Gospodarowanie pracą we współczesnym przedsiębiorstwie. Teoria i praktyka, Poznań: Wydawnictwo Forum Naukowe, pp. 193-206.

[7] Kalinowska-Sufinowicz, B. (2013) Polityka społeczno-gospodarcza państwa wobec pracy kobiet, Poznań: Wydawnictwo Uniwersytetu Ekonomicznego w Poznaniu.

[8] Kunasz, M (2004) 'Teoria kapitału ludzkiego na tle dorobku myśli ekonomicznej', in Manikowski, A., Psyk, A. (eds) Unifikacja gospodarek europejskich: szanse i zagrożenia, Warszawa: Uniwersytet Warszawski, pp. 1-10.

[9] Mincer, J. and Ofek, H. (1982) 'Interrupted Word Careers: Depreciation and Restoration of Human Capital', The Journal of Human Resources, vol. 17, No. 1, pp. 3-24.

[10] Mincer, J. and Polacheck, S. (1974) 'Family Investments in Human Capital: Earnings of Women', in Schultz, T. (ed.) Economics of the Family: Marriage, Children, And Human Capital, Cambridge: National Bureau of Economic Research, pp. 397-431.

[11] Mincer, J. (1958) 'Investment in Human Capital and Personal Income Distribution', The Journal of Political Economy, vol. VXVI, No. 4, pp. 281-302.

[12] Montesano, M. (2010) Teleworking Mum: The Essential Work From Home Guide for Parents, Melbourne: Red Bullet Research and Communications.

[13] Nilles, J.M. (1994) Managing Teleworking. Final Report, Los Angeles: Center for Effective Organizations.

[14] Ustawa z 26 czerwca 1974. Kodeks pracy, tekst jedn. Dz.U. z 2014 r., nr 0, poz. 1502, z późn. zm.

[15] Wiśniewski, J. (2007) Zatrudnianie pracowników w formie telepracy, Toruń: Dom Organizatora. 